\title{
Potential of Financial Technology in Transformation of Islamic Banking Sector in Oman
}

\author{
Umar Ahmed, Smiju Sudevan, Bashir Ahmad Fida
}

\begin{abstract}
The overall aim of this paper is to explore the potential of fintech in transforming Islamic banking industry in Oman. Islamic banks in Oman lack economies of scale, limited nationwide outreach, low penetration rate due to low level of public awareness. FinTech present a huge opportunity for the Islamic banking sector to be more competitive in the marketplace. Data and technology are converging, so, Islamic banks at the end of the day, must deliver excellent financial services at relatively low cost. Collaboration or joint venture between fintech firms and Islamic banks will allow Islamic banks to attract more customers, increase efficiency, but more importantly introduce a proposition for youth to be excited to join the industry and drive its development and growth.
\end{abstract}

Keywords: Potential, Fintech, transformation, Islamic banking, Oman.

\section{INTRODUCTION}

$W_{\text {ithin seven years into its existence, the Islamic }}$ banking sector in Oman has witnessed rapid growth in terms of total assets, deposits, financing, profits \& market share. The total assets of Islamic banks have reached $\$ 12$ billion as of March 2018 which accounts for $13.5 \%$ of the total market share. The deposits with the Islamic banking sector also increased from OMR2.385 billion in March 2017 to OMR3.158 billion at the end of March 2018, a growth of 32.4 percent (Times of Oman, September 2018). Islamic banking has registered a strong presence through a network of branches distributed in various governorates of the Sultanate with a total of 77 licensed branches, at the end of March 2018.Despite these successes, the industry is still at an infant stage with only a few Islamic banks and limited branches. Oman has only two full-fledged Islamic banks and four Islamic banks windows. Islamic banks face many challenges including lack of economies of scale, low market penetration rate and high competition from the conventional counterpart. The banking penetration level in Oman is around 14-16 per cent, compared with an average penetration level of 20 per cent in the GCC. This gives ample room for Omani institutions to grow, especially in the interior towns.

Manuscript received on March 23, 2021

Revised Manuscript received on June 23, 2021.

Manuscript published on June 30, 2021.

* Correspondence Author

Umar Ahmed*, Modern College of Business \& Science, Muscat Oman.

Smiju Sudevan, Modern College of Business \& Science, Muscat Oman.

Bashir Ahmad Fida, Modern College of Business \& Science, Muscat Oman.

(C) The Authors. Published by Blue Eyes Intelligence Engineering and Sciences Publication (BEIESP). This is an open access article under the CC BY-NC-ND license (http://creativecommons.org/licenses/by-nc-nd/4.0/)
That means, there is still space for Islamic banks to grow further, although there are challenges ahead (Times of Oman, November 2017). Besides, Islamic banks are concentrated within the cities with limited nationwide branches and thus they cannot be able to capture the potential customers.

Therefore, the way forward for the Islamic banking sector is to unleash the potential of Fintech to transform the industry. The Global Financial services industry has witnessed unprecedented change bought about by three core technological drivers, all linked closely to the fourth industrial revolution. They are automation, disintermediation and decentralization. Young, digitally native customers are the main stakeholders in drivingthe change (DIEDC report, 2018). The growth of computing power, combined with the decline in the cost of storing, processing, and collecting data, the exponential increase of accessible data and data sources, and the emergence of infrastructure and platforms where data can be shared and applications developed, contributed to the emergence and growth of theof Fintech (IOSCO report, 2017). Fintech leverage on the Internet, mobile devices and social media integrations make financial transactions more automated, user-friendly and more convenient, thus increasing customer satisfaction (Jamil and Seman, 2019).

According to Oman Observer (December 2017), 63 percent of Oman population have access to smartphones with an estimated 8 million smartphone devices registered. It's twice the population of the country. In addition, 74 percent of the people represent the banked adult tech-savvy population. This makes Oman very much ready to adopt the Fintech. Therefore, the objective of this paper is to explore the potential of Fintech in transforming the Islamic banking sector in Oman.

\section{FINANCIAL TECHNOLOGY PRODUCTS \& SERVICES}

Fintech is the use of technology to provide new and improved financial services (Thakor, 2019). The Financial Stability Board (FSB) defines fintech as "technologically enabled financial innovation that could result in new business models, applications, processes, or products with an associated material effect on financial markets and institutions, and deprovision of financial services. According to Thakor (2019), Fintech broadly covers four mainareas:(i) credit, deposits, and capital-raising services; (ii) payments, clearing and settlement services, including digital currencies; (iii) investment management services (including trading); and (iv) insurance. Part of the technological back Boneo fintech is the Blockchain technology.

\section{Published By:}

Blue Eyes Intelligence Engineering and Sciences Publication

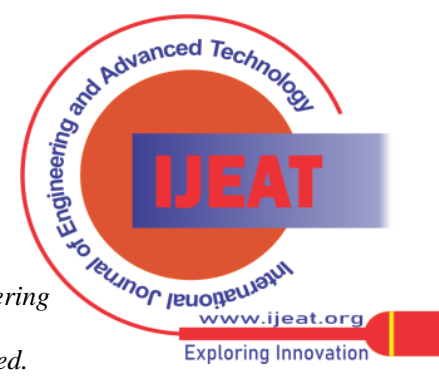


The Basel Committeeon Banking Supervision (2018) study on fintech financial services \& products reveal that the highest numbers of fintech service providers are in payments, clearing and settlement services, followed by credit, deposit and capital-raising services.

According to International Organization of Securities Commissions' (IOSCO) report (2017), fintech business models offer financial products or services in a sophisticated way using the internet. The models provide services which are traditionally domain of financial institutions. For instances, equity crowdfunding platforms intermediate share placements; peer-to-peer lending platforms intermediate or sell loans; robo-advisers provide automated investment advice; and social trading platforms offer brokerage and investing services.

Peer-to-peer (P2P) lending which also referred to as “marketplace lending' is the tool used to provide loan to individuals and businesses through online services that directly match lenders with borrowers without a bank. The borrower

appliesforaloan.TheP2Pplatformdoesapreliminarycreditanal ysis and assigns a"loan gradewhichisarisk classification.Then investors (potentiallenders)bidonthelistingwithloanamountsandinterest rates. The platform thencombinesqualifiedlenders'bidsintoasingleloan (Thakor, 2019). The novelty of this business model is that consumers and SMEs can access finance from both individuals and institutional lenders/ investors and in returns the lenders/ investors can earnmonthly interest income in addition to capital repayments(IOSCO report, 2017). P2P andcrowdfunding is a direct alternative to a bank loan but, instead of borrowing from a single source, businesses can obtain loans from dozens, sometimes hundreds of people willing to lend. Investors in this case often bid on the interest rate at which they would be willing to lend. Borrowers, therefore, accept loan offers that have the lowest interest rate (De Buysere, et.al 2012).The marketplace lending provides several benefits include increased flexibility in interest rates and offer better interest rates to secure the deal; increase access to loan for riskier borrowers, the loan is repaid through direct payments to the platform which then distributes to creditors \& disclosure requirements are similar to those of a bank ( Paolo, et.al. 2019). Some of the well-known P2P lending platforms in the U.S. are Lending Club Corporation (LC), Prosper Marketplace, Upstart, Circle BackLending, Funding Circle (co-foundedin the U Sand theUK), and Peerform. The types of loans P2P provides include consumer loans, business loans, invoice trading and mortgage loans (Thakor, 2019).

Perhaps the area in which fintech has had the greatest impact so far is in payments, clearance and settlement services. Cryptocurrency specifically Bitcoin is a virtual currency, which allows person-to-person transactions independently of the banking system(Thakor, 2019). Digital currencies are decentralised with loose form of control and transactionsare stored digitally on the Blockchain.This removes the need for a trusted financial intermediary like a bank to verify transactions (Catalini and Gans, 2016). Besides, consumers have also experienced innovations in the "digital wallets" (e.g., PayPal). These innovations enable consumers to complete online transactions without disclosing credit card details. Smartphones have facilitated the adoption of digital wallets in online environments. M-

Pesa was launched in Kenya in 2007 by mobile network partners Vodafone and Safaricom. It allows users to deposit money into an account linked to a cell phone, to send payments to sellers of goods and services, and to withdraw deposits for regular money. Thus, for all intents and purposes, it provides many of the essential services that banks provide, without having to rely on bank deposits. MPesa now services millions of customers worldwide and its services have expanded beyond payments systems to include lending, rental payments to landlords, and international remittances. Indeed, the future, digital wallets can transform the payments system that exists today by bringing together: peer-to-peer payments, tickets, boarding passes, keys to cars, homes and hotel rooms, and even personal identity verifications like driver's licenses and passport (Thakor, 2019).

Fintechalsosignificantly

change thewaywetradeandthewaywe manage money, including the provision of financial advice. High-frequency trading and etrading such as copy trading and robo -advising are fintech features of financial management services. Copytradingisusedtypically

inforextradinganditreferstothephenomenonofcopyingthetrad esof

successfultraders.Manysuccessfultradersprovideaccesstothei rtrades, eitherforafeeorforfree. D'Acunto et al. (2019) provide evidence that adopters of roboadvisingaresimilardemographicallytonon-adopters

butaremore active and have greater assets under management. Investors adopting robo-advising experience diversification benefits, getting better returns withlowervolatility.Allinvestorsincreaseattentionbasedononl ineaccount logins, and adopters are documented to reduce prominent behavioural biases,includingdisposition, trendchasing,andrankeffectbiases(IOSCO report, 2017),

Lastly, "InsurTech" is the branch of fintech that is dedicated to the insurance sector. The basic economics driving fintech in insurance is that connected devices (phones, watches, computers, etc.) in homes, cars and worn as personal gear gather huge amounts of personal information about individuals. This leads to "big data" that insurance companies can use to calculate risk more precisely and in a more dynamicwaythantheydoatpresent. Consumers can choose to utilize sensors and trackers provided by insurance companieswhich then generatedata thatinsurance companiescanusenotonlyinpricingtheinitialpolicy, but alsoindesigning adjustments that reward certain types of low-risk behaviours The end resultsaremorefinelycalibratedriskassessmentandpricing,withless pooling across customers with heterogeneous but ex ante indistinguishable risk profiles. Automobile and health insurance are two important segments for Insurtech (Thakor, 2019).

\section{ASSESSMENT OF THE POTENTIAL OF FINTECH IN BANKING SECTOR}

International Organization of Securities Commissions' (IOSCO) report indicated that fintech industry has cumulative investments of over $\$ 100$ billion and there were

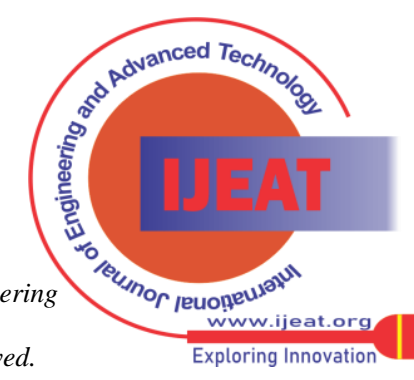


more than 8800 fintech companies as of November 2016. On an annual basis, global Fintech investments increased steadily between 2014 and 2017 from \$19.9bn to $\$ 39.4$ bn at a CAGR of $18.5 \%$.

This trend accelerated in the first half of 2018 when \$41.7bn was invested across 789 deals (FinTech Global, July 2018). According to the industry forecasts, the Middle East and North Africa (MENA) region's fintech market is predicted to grow by 270 per cent achieving a growth of approximately $\$ 125$ million a year to reach $\$ 2.5$ billion in 2022.The MENA fintech market is currently worth $\$ 2$ bn but increased annual investment will boost the number of fintech start-ups from six in 2005 to around 250 by 2020.The market's largest segment is Digital Payments with a total transaction value of $\$ 41,447$ million in 2018.Total transaction value is expected to show an annual growth rate (CAGR 2018-2022) of 12.8 per cent resulting in the total amount of $\$ 67,004$ million by 2022.Four countries account for almost 75 per cent of all start-ups in the MENA region. the UAE, Lebanon, Jordan and Egypt.High smartphone penetration, young and tech-savvy people and the government's support are all turning the region into an attractive hub for fintech (Oman Observer, October 2018).

It is noteworthy mentioning that digitalisation of financial services is still the greatest opportunity for fintech with banks being the largest investors. Changes in customer preferences and technological advances have pushed large banks to take a lead in digitalisation in the region followed by Islamic finance. Naveen Bharadwaj adds that to evolve with customers' preferred trends, stay ahead of competition and achieve a cashless economy, all major banks and financial institutions are placing huge strategic bets on blockchain, robotics, artificial intelligence and predictive analytics under the umbrella of Fintech (Oman Observer, October 2018).

A recent Boston Consulting Group study showed that over the next five years, corporate banks that remain digital laggards could see profits drop by as much as $15-30$ percent relative to their digitally fast-moving competitors.The large established financial institutions are embracing the change, with $74 \%$ of financial institutions investing in data analytics, $34 \%$ in Artificial Intelligence (AI), and with $77 \%$ expecting to adopt blockchain by 2020 (DIEDC report, 2018). EY report (2017) analysis of 45 major global banks reveals that while all banks are engaged with Fintech in one way or another, only around a quarter are extensively engaged due to barriers to collaboration with Fintech. The report added that in 2016, the average return on equity (ROE) for the largest 200 global banks was just over 7.1\%. To achieve a ROE of $12 \%$, the top 200 global banks need to increase their revenues by $15 \%$ and reduce costs by $13.7 \%$. Engaging with Fintech, part of a broader banking ecosystem, will help banks drive down costs, innovate and enhance customer service.

There are four approaches in which banks can used to deal with Fintech companies and these include: Firstly, banks invest their own capital in Fintech start-ups by establishing a dedicated in-house venture capital or strategic investment arms or setting up an independent venture capital funds. Secondly, banks can enter into collaboration with Fintech companies through various strategies such as utilizing products or platforms developed by Fintech for example, a bank teaming up with a robo-advice FinTech to offer investment management services. Besides, banks can also collaborate as a network to develop and test new technologies and solutions. In relation to peer-to-peer (P2P) lending, a bank might refer a small business that falls outside the bank's risk appetite to a P2P FinTech. Banks might have Joint ventures or co-created services with Fintech companies. For instances, a bank partnering with a FinTech firm to launch a digital marketplace. Thirdly, banks can develop their in-house FinTech products and services. For example, banks can innovate payments and roboadvisors to a suite of e-banking products. But, historically, they have been slow to innovate new products, given the complexity of their businesses and strict regulatory and compliance environment in which they operate. Lastly, banks can acquire a FinTech company to increase a bank's digital footprint and short-cut the development of new technology. this is typically banks' least preferred strategy, but we observe large global and regional banks taking stakes in online competitor (EY report, 2017).

\section{ROLE OF FINTECHIN ISLAMIC BANKING INDUSTRY}

Fintech's penetration into Islamic finance is still in its infancy with a relatively small number of participants. However, the potential is enormous for traditional Islamic finance industry. The rise of Fintech has opened a world of possibilities for Islamic Financial Institution (IFIs). It is a win-win for both situations whereby IFIs can leverage on their ATM Network, branch infrastructure and integrate with Fintech's platform to increase their products and services. IFIs will have to be at the forefront of the latest development in Fintech financial business models and collaborate with fintech firmsto capture unbanked market(Jamil and Seman, 2019).

There are several case studies which show the success of Islamic Fintech firms partner with Islamic banksto provide solutions to savvy-techy consumers. For instance, Waqfe is a fintech digital community banking platform for deposit mobilization. The solution is designed for Islamic banks to build a loyal customer base, attract longer tenor deposits, improve cross-sell and generate higher annual customer value. Waqfe enables Islamic banks to acquire digital-ready customers through an engagement model that is built around their lifestyle needs. Its offerings include an integrated digital saving account, personal financial management tool, and a community marketplace. The second case, Oman's Alizz Islamic Bank partners with Irelandbased Ubanquity to provide customers with enhanced experiences. Ubanquity signs an agreement with Alizz Islamic Bankto provide excellent Islamic banking products and services. Ubanquity Systems Ld. is a leading white-label omnichannel solution provider to banks and financial institutions in Ireland. Ubanquity's API driven Platform integrates with any Core Banking System, ATM switch, Payment Gateway, and all Social Networks(DIEDC report, 2018).

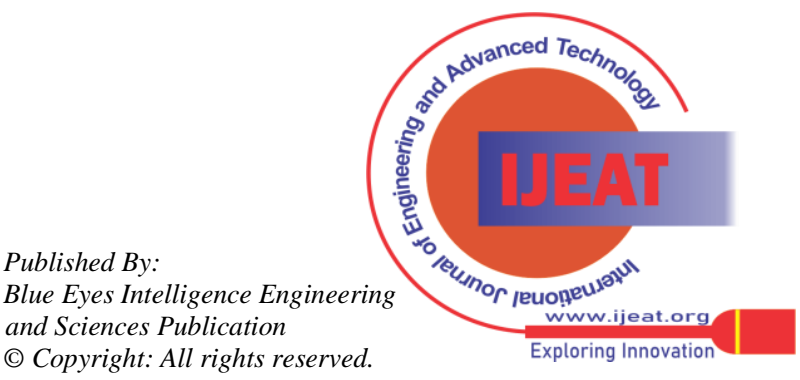




\section{CONCLUSION}

Despite some success, Islamic banks in Oman are struggling to convince the public that they truly different from their conventional counterpart. This hinders to some extend their penetration rate as it is difficult for the sector to win the hearts and minds of their target market.

Besides, Islamic banks face high competition from the established conventional banks given the fact that the Islamic banks have no economies of scale and limited branches. In turn, this increase costs and lower their profit margin. The way forward for Islamic banking sector in Oman is to embrace fintech through collaboration and joint venture with fintech companies to remain relevant to savvytech consumers and competitive in the market.

\section{REFERENCES}

1. AnjanV.Thakora (2019). Fintech and banking: What do we know? Journal of Financial Intermediation

2. EY report (2017).Unleashing the potential of FinTech in banking. Publisher: Ernst \& Young Global Limited. Available at: https://www.ey.com/Publication/vwLUAssets/ey-unleashing-thepotential-of-fin-tech-in-banking/\$File/ey-unleashing-the-potentialof-fin-tech-in-banking.pdf

3. DIEDC report (2018). Islamic Fintech report: Current Landscape and Path forward. Dubai Islamic Economy Development Centre. Available at: https://www.dinarstandard.com/wpcontent/uploads/2018/12/Islamic-Fintech-Report-2018.pdf

4. K. De Buysere, O. Gajda, R. Kleverlaan, D. Marom, and M. Klaes(2012). A Framework for European Crowdfunding.

5. Oman Observer ( February, 2020). Fintech in Islamic Finance is gaining Momentum with Youth. Available at: https://www.omanobserver.om/fintech-in-islamic-finance-gainsmomentum-with-youth/

6. Times of Oman November (2017). Islamic banks post $32 \%$ growth in financing. Accessed at: https://timesofoman.com/article/122448

7. FinTech Global (July 2018). 2018 is already a record year for global FinTech investment. Available at: https://fintech.global/2018-is-already-a-record-year-for-globalfintech-investment

8. Jamil, N. N., \&Seman, J. A. (2019). The Impact of Fintech On The Sustainability Of Islamic Accounting And Finance Education In Malaysia. Journal of Islamic, Social, Economics and Development (JISED), 4(17), 74-8

9. IOSCO (2017).Report on Financial Technology. International Organization of Securities Commissions. Available at: https://www.iosco.org/library/pubdocs/pdf/IOSCOPD554.pdf

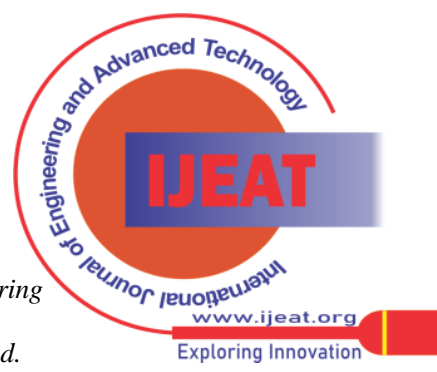

